\section{RNase $H$ and Its Effects on PCR}

BioTechniques 32:1224-1225 (June 2002)

RNase $\mathrm{H}$ was originally described as an enzyme that specifically degrades RNA in an RNA:DNA hybrid and is inactive on ss- or dsRNAs and DNAs alone (2). RNase $\mathrm{H}$ treatment is recommended during cDNA preparation because the RNase $\mathrm{H}$ activity, originally present in reverse transcriptases, has been removed in some cloned enzymes. These modified enzymes yield more cDNA, so they are now more routinely used in the preparation of cDNA. It is believed that low copy number transcripts may be more readily detected after RNase $\mathrm{H}$ treatment, but systematic studies demonstrating the effects of RNase $\mathrm{H}$ have not been reported. We show that the template of one gene of a multigene family becomes more readily available for PCR amplification only after RNase $\mathrm{H}$ treatment, while two other genes are not affected by RNase $\mathrm{H}$ treatment.

We were studying the relative expression levels of three related $\mathrm{Na}^{+} / \mathrm{Ca}^{2+}$ exchanger genes NCX1, NCX2, and NCX3. These three genes are about $65 \%$ identical at the amino acid level (3) and are all expressed in brain tissues. We modified the quantitative end-labeled RT-PCR technique (1) to determine the relative proportion of these three genes. In this study, we used PCR primers com plementary to conserved regions between these three genes. One of the primers was end-labeled with ${ }^{32} \mathrm{P}$ ATP. After PCR, the products were run on a sequencing gel, and the relative amount of the various transcripts could be determined based on size because of naturally occurring internal deletions that exist between these three genes. The position of the band indicates a specific gene (either NCX1, NCX2, or NCX3), and the band intensity reflects the amount of that transcript present in the sample.

Forward primers were mixtures of oligonucleotides identical to each of the three genes. The forward primer mixture contained two primers differing only by a single base in the middle of the sequence $5^{\prime}$-TGGAGC(A/G)TCTTTGCCTAT- $3^{\prime}$. The reverse primer mixture contained three individual primers, one identical to each of the three genes. These primers differed near the middle of the oligonucleotides by as much as three bases (NCX1 to the other two genes) and as little as a single base (between NCX2 and NCX3) when compared to the corresponding gene sequences. The reverse primers used for each gene were 5'-NCX1-CGGTAAA ATGCTCGGCTCTT-3', 5'-NCX2-CG GTAGAAGGCACGGCTCTT- $3^{\prime}$, and 5'-NCX3-CGGTAGAAAGCACGGCTCTT $-3^{\prime}$. The forward primer mixture was end-labeled with $32 \mathrm{P}(31 \mathrm{cpm} /$ pmol) before amplification with unlabeled reverse primers.

cDNA was prepared from rat brain using $1 \mu \mathrm{g}$ RNA SUPERSCRIPT II $^{\mathrm{TM}}$ RNase $\mathrm{H}$ reverse transcriptase (Invitrogen, Carlsbad, CA, USA) using random hexamers according to the manufacturer's instructions. After terminating cDNA synthesis, $1 \mu \mathrm{L}$ (2 U) RNase $\mathrm{H}$ (Invitrogen) was added and incubated at $37^{\circ} \mathrm{C}$ for $20 \mathrm{~min}$ in samples treated with RNase H. After addition of the cDNA, the reactions were initiated by heating at $94^{\circ} \mathrm{C}$ for $2 \mathrm{~min}$ and then using a protocol consisting of incubation at $40^{\circ} \mathrm{C}$ for $1 \mathrm{~min}, 72^{\circ} \mathrm{C}$ for $1.5 \mathrm{~min}$, followed by $94^{\circ} \mathrm{C}$ for $1 \mathrm{~min}$ for 30 cycles. Sam ples were taken out of the tube during the amplification process, and a small amount of the sample $(1.5 \mu \mathrm{L})$ was loaded on a $5 \%$ sequencing gel. After electrophoresis, the gel was dried and exposed using the Storm ${ }^{\mathrm{TM}}$ phosphorimaging system (Amersham Biosciences, Piscataway, NJ, USA) and quantified (1).

To demonstrate that amplification is representative of the template, we added equal amounts of DNA representing these three genes. The band intensity of labeled products agreed with the relative proportion of template added (Figure 1, lane 1). Additional experiments varying the ratio of the different templates resulted in product ratios consistent with starting template ratios (data not shown). When we used this technique to study the relative contribution of transcripts for these three NCX genes in adult rat whole brain, NCX1 was predominant, levels of NCX3 were less, and barely detectable levels of NCX2 gene products were observed (Figure 1, lane 2). This result was surprising since others studying the rat brain found NCX2 to be at moderate levels. The cortex of the brain especially has been previously reported to express elevated levels of the NCX2 gene product $(4,5)$. When we used cDNAs made from telencephalon RNA (which contains the cortex), we noted a dramatic difference in the intensity of the band for the NCX2 gene transcripts depending on whether the cDNAs had been treated with RNase $\mathrm{H}$ or not (Figure 1, lanes 3 and 4). Before treatment with $\mathrm{RNase} H$, the band intensities for the three genes were comparable to that of whole brain. After RNase $\mathrm{H}$ treatment, the relative contribution of NCX2 increased dramatically. This result was quite surprising and suggested that the NCX2 transcript was less accessible to PCR. The NCX2 gene contains only $11 \%$ higher $\mathrm{G}+\mathrm{C}$ ratio when compared to NCX1 and NCX3. This difference in $\mathrm{G}+\mathrm{C}$ ratio for the whole gene is accurately reflected in the regions that were used for amplification. The same characteristic of increased amounts of NCX2 transcript after RNase $\mathrm{H}$ treatment has been detected in cDNAs from different rat strains of whole brain. Similarly, RNase H treatment of cDNAs from different regions of the rat brain shows a specific increase in the relative proportion of the NCX2 transcript (data not shown). Also, in cDNA primed with oligo dT, we observed the same difficulty in am-

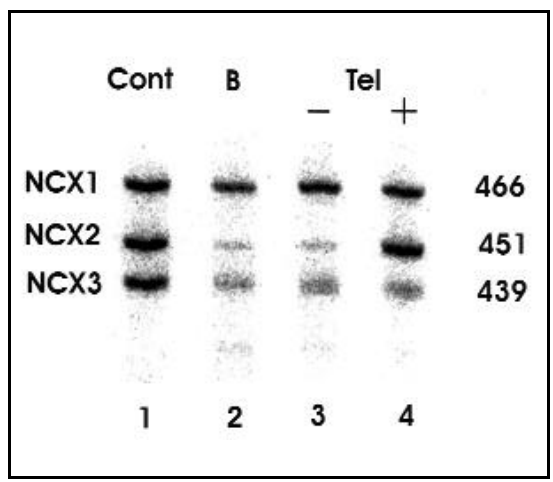

Figure 1. Autoradiograph of PCR products for NCX genes. Lane 1 represents an equal molar addition of DNAs for the three genes (Cont). Lane 2 shows the PCR products from rat whole brain without RNase $\mathrm{H}$ treatment (B). Lanes 3 and 4 display PCR products from telencephalon cDNAs with (+) or without (-) RNase H treatment, respectively (Tel). Products are from the twenty-first PCR cycle. 
plifying the NCX2 transcripts unless RNase $\mathrm{H}$ treatment of the cDNA was used. This increased detection of NCX2-specific expression after treating cDNAs with RNase $\mathrm{H}$ is consistent with a lack of availability to the tem plate during the PCR.

To determine if extended denaturation coupled with hot-start PCR could replace the need for treating the cDNAs with RNase $\mathrm{H}$, we used RNA from the telencephalon to prepare cDNA. Sam ples of telencephalon cDNA were am plified with and without RNase $\mathrm{H}$ treatment using different denaturation conditions. We show in Figure 2 that 5 min denaturation at increased temperatures in the absence of RNase $\mathrm{H}$ treatment does result in increased NCX2 transcript but not to the level of RNase $\mathrm{H}$ treatment. Extended denaturation conditions did not alter the ratio of transcripts from NCX1 and NCX3.

In our study to quantify the relative amounts of the NCX multigene family members, we were able to observe a gene-specific difference in the accessibility depending on RNase $\mathrm{H}$ treatment to subsequent amplification. We present these data to demonstrate the surprising sensitivity that is provided when template is presented to primers

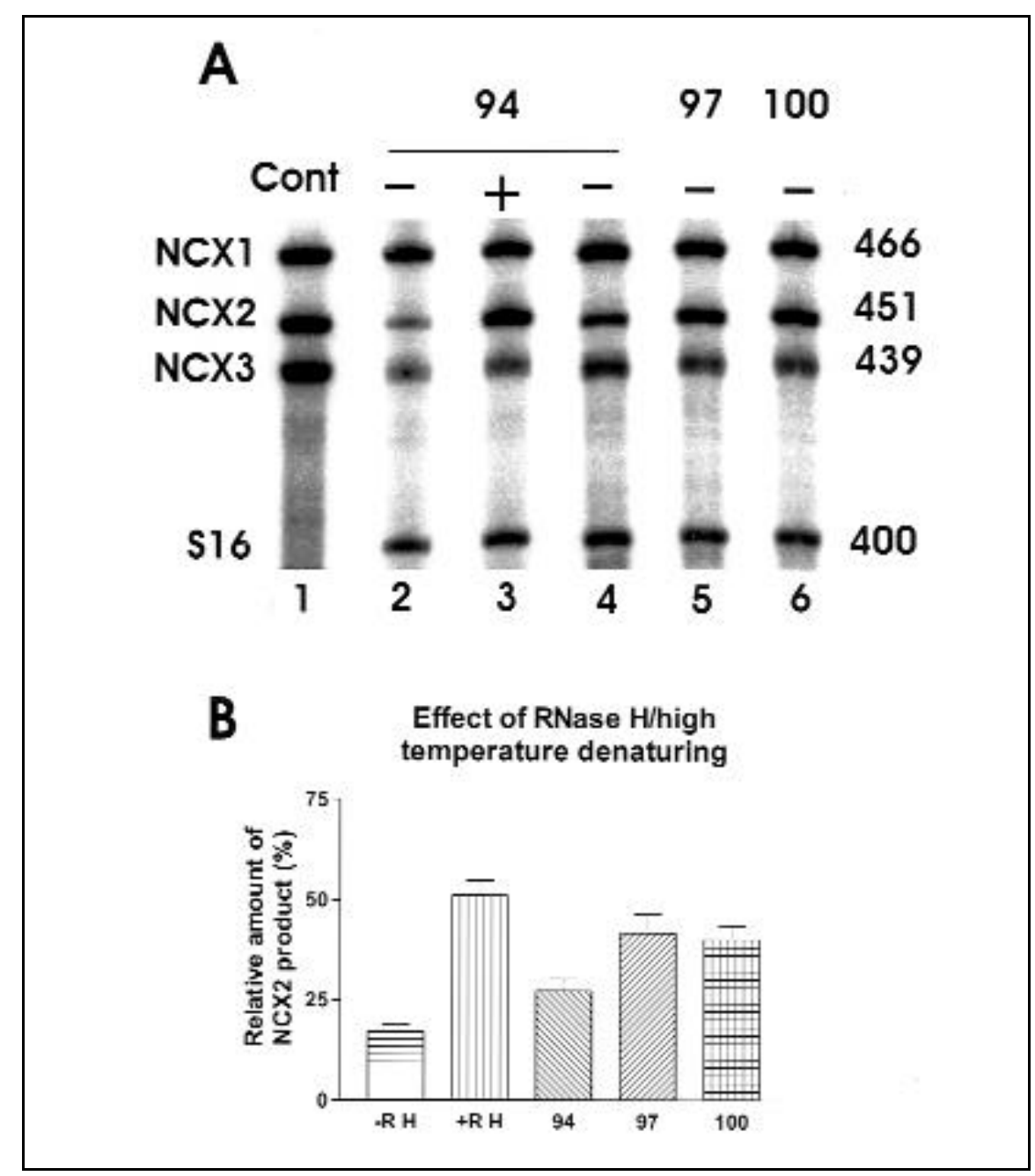

Figure 2. Autoradiographs of PCR products of control DNA and rat telencephalon cDNAs. (A) Lane 1 represents an equal molar addition of DNAs for the three genes (Cont). Lanes 2 and 3 show the PCR products from telencephalon cDNAs with (+) or without (-) RNase $\mathrm{H}$ treatment denatured at $94^{\circ} \mathrm{C}$ for 1 min (94). Lanes 4-6 display PCR products from telencephalon cDNAs using hot-start PCR with a 5-min denaturation time at the temperature shown without (-) RNase $\mathrm{H}$ treatment. S16 is a control band representing the S16 ribosomal protein transcript for detecting equal amounts of loading in each lane. Samples are from the twenty-first PCR cycle. (B) Bar graph represents the relative amount of the NCX2 transcript when compared to the other NCX genes.

under different conditions (i.e., with and without RNase $\mathrm{H}$ treatment). We show that extensive denaturation conditions (very high temperatures and longer denaturation times) may minimize the inhibition in amplification to particular sequences if RNase $\mathrm{H}$ treatment is not or cannot be used.

\section{REFERENCES}

1.He, S., A. Ruknudin, L.L. Bambrick, W.J. Lederer, and D.H. Schulze. 1998. Isoformspecific regulation of the $\mathrm{Na}^{+} / \mathrm{Ca}^{2+}$ exchanger in rat astrocytes and neurons by PKA. J. Neurosci. 18:4833-4841.

2.Miller, H.I. and G.N. Gill. 1975. Adrenal cortical ribonuclease $\mathrm{H}$ (hybrid). Proc. Soc. Exp. Biol. Med. 148:151-156.

3.Nicoll, D.A., B.D. Quednau, Z. Qui, Y-R. Xia, A.J. Lusis, and K.D. Philipson. 1996. Cloning of a third mammalian $\mathrm{Na}^{+}-\mathrm{Ca}^{2+}$ exchanger, NCX3. J. Biol. Chem. 271:2491424921.

4.Sakaue, M., H. Nakamura, I Kaneko, Y. Kawaski, N. Arakawa, H. Hashimoto, Y. Koyama, A. Baba, and T. Matsuda. 2000. $\mathrm{Na}^{+}-\mathrm{Ca}^{2+}$ exchanger isoforms in rat neuronal preparations: different changes in their expressions during postnatal development. Brain Res. 881:212-216.

5.Yu, L. and R.A. Colvin. 1997. Regional differences in expression of transcripts for $\mathrm{Na}^{+} / \mathrm{Ca}^{2}+$ exchanger isoforms in rat brain. Brain Res. Mol. Brain Res. 50:285-292.

This work was partially supported by National Institutes of Health grant no. NIH HL62521. We thank Dr. M. McCarthy from the Department of Physiology, University of Maryland for supplying the telencephalon tissue. Address correspondence to Dr. Dan Schulze, University of Maryland, Department of Microbiology and Immunology, Baltimore, MD, 21201 USA. e-mail: dschulze@umaryland.edu

Received 20 December 2001; accepted 8 March 2002.

Swamy K. Polumuri, Abdul Ruknudin, and Dan H. Schulze University of Maryland School of Medicine Baltimore, MD, USA

For reprints of this or any other article, contact Reprints@BioTechniques.com 